\title{
A Study on National Competency Standard Career Education for Middle-aged Male Retirees
}

\author{
Jae-kwan Jung ${ }^{1}$, Dong-il Kim², Mi-Na Lee ${ }^{3}$ \\ ${ }^{I}$ The Doctor's Course, Department of Human Service Education, Kwangshin University, South Korea, \\ jjk1116@hanmail.net \\ ${ }^{2}$ Visiting Professor, Faculty of Welfare Counseling Convergence, Kwangshin University, South \\ Korea, ks04014@hanmail.net \\ ${ }^{3}$ Professor, Welfare Counseling Convergence Department, Kwangshin University, South Korea, \\ Imn4780@naver.com
}

Corresponding author: $\mathrm{Mi}$-Na Lee

\begin{abstract}
The focus of this study is on the development of the National Competency Standard(NCS) career education on the quality of life for middle-aged and elderly men's retirement generations. The most important thing in the Career Education Development Manual is to apply the appropriate types of activities for the development of necessary core competencies at each stage based on the level of career activities. National Competency Standards (NCS) is a systematic arrangement of knowledge, skills, etc. required to perform their duties at an industrial site by industry sector and level. In other words, it was stipulated that on-site application is possible to express each individual's abilities by switching from academic-centered education to practical-oriented education. Through this, They intend to develop a lifelong learning curriculum that develops and operates education courses using NCS and standardizes practical and systematic knowledge and skills as well as securing the quality of education. This study seeks to help middle-aged and senior citizens with educational background, knowledge, and professional social experience to have the opportunity to design successful retirement in pursuit of the positive meaning of life for retirement generations.
\end{abstract}

Keywords: Middle-aged Men, Retirement, Generation, NCS, Career, Education, Quality of Life, Lifelong Learning

\section{Introduction}

\subsection{The Necessity of Research}

The Fourth Industrial Revolution points to the need and direction of innovation and change in vocational education in our society. Existing jobs are disappearing or new jobs, high value-added industries, and convergence jobs are emerging. This is said to mark the turning point of society into an era of lifelong occupation, not a lifelong job[1].

In addition, rapid development in production and information and communication technology in the era of internationalization has accelerated global openness and integration in the 21 st century. As a result, knowledge industries based on knowledge services such as information industries, cultural industries, and financial industries are quickly shifting to production systems, which account for a larger proportion. Fostering talent to lead the knowledge-based society in the 21 st century is the flow of

Received: July 23, 2021; $1^{\text {st }}$ Review Result: September 09, 2021; $2^{\text {nd }}$ Review Result: October 23, 2021 Accepted: November 30, 2021 
lifelong learning and the key to lifelong education[2]. To catch up with knowledge as society changes from labor-intensive industries to expertise-oriented industries, or knowledge-based industries, it is time to come up with new plans for the development of vocational skills at any point in life[1]. In particular, the period from retirement to death is increasing as the life expectancy of the elderly increases in the 21 st century[3]. As such, the job market today is losing the concept of a lifelong job due to the expansion of the life cycle and the labor market is increasing with the elderly population[4].

In addition, the acceleration of aging and the retirement of baby boomers are in full swing, raising interest in the life satisfaction of the extended retirement generation. In Korea, preparation for the compressed aging population along with economic development is officially insufficient, which is adding to the anxiety about old life[5]. In the case of the elderly, the quality of life of the retirement generation depends greatly on how they accept and deal with these changes[6] as they face a "retirement" that undergoes drastic changes in their social and economic status. The sense of identity of men can be established through the work of occupation[7]. Moreover, in the case of male retirees in our country, the loss of occupational role is likely to be perceived as a life crisis work is an important factor that has determined a person's value before and after retirement. A man's retirement does not just mean the time he has lived, but also includes personal experiences and social changes in his life and leads to psychological resources to find a new life after retirement[4]. Thus, jobs are an important source of selfrespect And by allowing individuals to adapt to retirement through jobs, these people find meaning in their lives.

As the proportion of the retirement generation population increases due to aging and the quality of life of the elderly greatly affects the quality of life of the entire nation, improving satisfaction with old age is becoming a major social issue in the national social policy. Therefore, the quality of life of elderly retirees is needed due to social and economic development, and social discussions are required to improve their psychological, social, and subjective life satisfaction. This is because life satisfaction is not a quantifiable concept, but rather a qualitative concept at the same time. Nevertheless, most agree to use life satisfaction as a measure of successful aging[8]. As a measure of successful aging, life satisfaction is linked to subjective thoughts throughout one's life and is widely used as an important indicator of a person's successful life[9].

A retirement is a life-determining event later in life, and an event that leads to a withdrawal from production activities and a transfer to a non-professional position, which is an important event for individuals to easily develop economic and social deficiencies[10]. Furthermore, jobs are not just a means of living or economic stimulus, so job losses can lead to a loss of identity due to a decrease in income, a decrease in social networks, and a lack of belonging in a generation that has lived separating roles according to sexual biology traditionally[11]. In addition, social relationships will change after retirement, which will be affected by daily life, and living environment. The stigma that retirees are unproductive and incompetent prevents retirees from establishing social roles and experiences a crisis of identity[12]. About concerning to this social phenomenon, the negative perception of retirement in the past was prevailing as an elderly person who did not need to leave society[13].

\subsection{The Research Problem}

The average life expectancy of humans has been prolonged due to the development of medical technology and the improvement of lives, however, in reality, elderly retirees are challenged with psychologically instability. Due to the rapid aging of the population, the researchers aim to answer the following questions: First, what NCS career education will best prepare middle-aged and elderly men for retirement? Second, what changes in the quality of life do the middle-aged and elderly male retirement generation experience in relation to the NCS career education development? 


\section{Theoretical Background}

\subsection{Quality of Life for Male Retirees}

The concept of retirement can be defined in a variety of ways according to the researchers' perspectives. However, the universal concept of retirement means switching from full-time employment to part-time or that the employment relationship is completely terminated and that there is no income for a given period time[14][15]. Today's retirement is a gradual process of reducing the number of years of work rather than quitting work altogether[16]. That is, retirement means quitting work and stepping down. And he said it was a case of no intention of returning to the labor market[17].

It has been a passive attitude that people think of retirement as an "eternal vacation and rest". These days, the meaning and standards of retirement of middle-aged and elderly are also changing. As the words, "third life," and "successful aging" implies new pursuits, challenges, and times of success[18]. This change is now possible in retirees because of the development of science, advances in medical technology, and self-management, which have extended the physical health age by several decades[13]. In addition, the elderly generation is increasingly educated and now there are more retired professionals than the past generation It is particularly important to ensure that retirees with these educational, knowledgeable, and professional social experiences have the opportunity to design a successful retirement in their old age[13]. The reality of general retirees' is being studied a lot, but in the social importance of professional retirees, They recognized the importance of recycling retirees capabilities and studied requirement analysis on the successful aging of professional retirees[13]. The differences in life before and after retirement affect mental health and it is evident a lot for retirees. Modern concerns and studies about improving retirees' health and cognitive function may work in more important ways. Analysis of the effectiveness of mental health and cognitive functions of retirement needs to be looked at in the future with the aim of "preventing them in the medical field". This is because cognitive decline and mental health risk factors include lifestyle and psychological and social factors[19].

The reality is that the population change of society is rapidly progressing beyond an aging society to a high-aged society, so efforts to recognize and maintain mental health risks in advance are necessary for the healthy life of humans[20][21].

The first age: a time of dependence and education and training as a time of birth-formal education; a time of employment-economic independence and obligation; a time of self-improvement as a time of retirement; a time of self-fulfilling (true) and well-being. In particular, the third age refers to a period of self-fulfilling, where most of the post-retirement periods are 55-60 to 75-80 years of age or older, and when self-fulfilling activities are truly possible to plan and live and feel satisfied[13]. Aging does not only mean biological decline or reduction, but it also means that the aging process is progressing about to with concerning psychological and social factors. Successful aging means minimizing disease and disability, maintaining high cognitive and physical functions, and actively participating in life through active human relationships and productive activities, where active participation in life includes ideal labor, volunteerism, religious life, and family care[18].

In the relevant study, there is a change in the life goals of retired men facing successful retirement[22]. A useful framework that can explain the perception of successful old age of men in a multifaceted relationship must describe the experience in changing life goals and look at the meaning of these experiences through narrative methods. In other words, it is a study in which men who retire from work understand life in the transition period of their old age. It was said that human beings need a balanced process of pursuing life-oriented goal while setting and pursuing life goals, and that they can find out what the important meaning of life is in the process and modify their goals. Therefore, the attitude toward old age is meaningful in implementation from the life of "I expect in the future" to the life of "selfawareness and practice." It also includes the meaning of the value of continuing to work after retirement. 
The retirement generation needs adaptability as an important skill in the second cycle of life to balance life and work. Work is still focused on achievement goals, but health should be considered first for anyone, and the changed appearance of finding a balance of life in 'work, family, self and community' must find relationship, communication, and health.

Work is still focused on achievement goals, but health should be considered first for anyone, and the changed appearance of finding a balance of life in 'work, family, self, and community' must find a relationship, communication, and health. There is also a study that examines the effects of social retirement anxiety on psychological well-being in the middle-aged[23]. Retirement anxiety among the middle-aged showed significant results in occupational type, income satisfaction, and future economic activities: social support varied depending on the occupational type and academic background: and psychological well-being was significant in occupational type, monthly income satisfaction, and future economic activities: social support varied depending on occupational type and academic background: and psychological well-being was significant in occupational type, monthly income satisfaction, and future economic activities. The lower the social retirement anxiety, the higher the psychological wellbeing, and the higher the social support, the higher the psychological well-being. To increase psychological well-being, reducing retirement anxiety requires continuous education before and after retirement and personalized support.

\subsection{Self-respect for Retirement Generations}

The most important part of the retirement preparation generation is self-respect. It is formed in childhood[24], but once formed, self-respect has raised the link between various events experienced in the social environment and changes in their experience[25]. It is said that the beginning of self-respect is achieved through acceptance and respect from childhood and can change with age. Self-respect develops in one's way, dealing with the values, experiences of success, personal expectations and desires for success and failure, and negative feedback or criticism that others are evaluating about oneself[26][27]. Psychosocial support is said to boost self-esteem and have a positive impact on oneself and the surrounding environment in the labor markets. In particular, the adult life of male retirees is a period of psychosocial development based on social and cultural factors, and self-respect is influenced by social skills such as interpersonal and economic activities, etc.[25]. Self-respect is recognized as a positive emotion, and a person with high self-esteem is known to play an active role in social groups and express his or her opinion effectively, and engage realistically in achieving individual goals[28]. Therefore, people with high self-esteem actively play a given role in the home and work areas, and relationship satisfaction increases in the process of actively expressing positive emotions.

If you have high self-respect, you respect yourself, acknowledge yourself as a valuable person, and consider yourself successful and valuable. The degree to which the ideal concept of one's self and the actual concept are consistent. In other words, they believe that they can be happy themselves and have confidence in their ability to overcome hardships in life by controlling their emotions. Therefore, selfrespect is an assessment of oneself, which is to think of oneself as a respectable and valuable being[1]. The formation of self-respect separately presented self- awareness and self-concepts by evaluating themselves, comparing themselves with people from groups that do not belong to others[29]. Selfrespect is acquired by interaction with the social surroundings and maintained self-image by experience and perception of relationships with others[30]. In domestic studies, self-respect and career path also showed that the higher self-respect, the higher career maturity, the higher one can choose a job that can satisfy one's needs, thereby maintaining cognitive balance[31].

In a study comparing career and self-respect between youth and middle-aged persons, the high education level and socioeconomic status, the higher the self-respect and the higher the connection with family and social relationships. It is said that it depends on the marriage status and that the support of 
the spouse affects the respect of the elderly. Furthermore, satisfying the desire for social interaction and satisfaction from social relationships have a positive effect on self-respect[25][28]. The process of forming self-respect is explained in four principles[29].

First, people evaluate themselves according to other people's assessments. They consider themselves valuable or worthless based on the assessment of others. Second, an individual evaluates oneself by comparing himself/herself to the group he/she belongs to or other groups of people who do not belong to. Third, one's ego is formed by observing one's self. Fourth, self-respect is closely related to selfconcept and is influenced by the relative importance of self-concept components. Therefore, self-respect is acquired through interaction with social surroundings, and self-image is maintained through experience and perception of relationships with others. Self-respect can have a huge impact on the dignity and value of individual life and is formed through interaction with others.

\subsection{Self-determination of Retirement Generations}

Self-determination is a branch of psychological theory to explain human motivation. Motivation has been noted as a variable that accounts for individual temperamental differences and predicts behavior reasonably and has been described in the direction, focus, maintenance, promotion, and creative performance of behavior[32]. The intrinsic motivation for representing self-determination emphasized the importance of internal grounds for individual personality development and behavioral control[32]. The human motivation was divided into intrinsic and extrinsic motives[33].

The intrinsic motivation is the source of the power to induce action, and the task itself is said to have improved creativity, self-respect, and well-being by acting out of pleasure or interest. It was also said that self-crystallinity is a determinant of intrinsic motivation[33]. On the other hand, external motivation is acting on external stimuli, such as compensation or punishment from outside, which is generally considered to degrade intrinsic motivation[32]. Individuals can have self-determination even if there is an intervention of external motivators, and this finding of external motivators may play a role in helping rather than hindering intrinsic motivation[33]. High self-determination is said to be a determinant of intrinsic motivation, and to have a psychological need for autonomy, competence and relatedness[32]. Intrinsic motivations promote creative behavior, positive behavior, self-esteem, life satisfaction, and persistence[32]. If they look at the components of autonomy, competence, and relationship of selfdetermination, it is like goodness. First, autonomy is the belief that the perceived cause of one's behavior is recognized as being in itself and that one is the subject and regulator of one's behavior[34]. Autonomy is the basic desire to experience one's actions as voluntary without being forced by others, and its ability is properly exercised by ensuring autonomy. In other words, in the theory of self-crystallinity, there are external motivations (external regulation, imposed regulation, identified regulation, integrated regulation) and intrinsic motivations depending on the extent to which the level of autonomy is low[35].

Second, competence is the perception that an individual wants to feel competent and is satisfied when he or she experiences the opportunity to use his or her abilities or skills in an interaction with the social environment, and the higher he or she perceives competence during the task, the greater the intrinsic motivation for that behavior[32]. Support for this ability promotes internalization of motivation and externally synchronized behavior contributes to promoting self-regulation. That is, if you do not feel confident in performing the target action, you cannot internalize the control of the action[36]. To meet the competence, the intrinsic motivation must be enhanced and positive feedback must appear in the intrinsic motivation. Third, relatedness is the feeling of exchanging attention with others and being connected to society[32]. They theorized that relationships are related to the basic needs of competence and autonomy and the inner motivation[32] and that the social context affecting the perception of autonomy and competence affects the inner motivation. Therefore, relationships indirectly influence maintaining intrinsic motivation, and the three basic psychological needs continue to interact and affect 
human development.

\section{Development of NCS Career Education}

National Competency Standards (NCS) refers to the organization of the state's knowledge, skills, etc. required to perform its duties at industrial sites by industry sector and level. Standard is the most common or average thing in a mix of different categories, i.e., the basis or basis for determining the degree or nature of things, and it is the basic meaning of 'compliance'. According to the utilization of the national standards for job competence, the importance of the role of education and businesses was defined so that they could be applied to a job and practice-oriented education, i.e., fieldwork, in academic-oriented education. Through this, national job competency standards can be developed and operated by national institutions, and learning materials and tools that standardize practical and systematic knowledge and skills as well as securing quality of education can be developed[4]. Therefore, based on the educational needs of male retirees, they would like to present a national job competency standard program. The educational needs of a male retiree are environmental needs, expressive needs, social contribution needs, and transparency needs[37]. First, the desire to adapt to the environment is to change and receive education to maintain normal function in society because ability and knowledge decrease with their aging. Second, expressive demands seek satisfaction from themselves, such as voluntary physical exercise, social activities, and new experiences. Fourth, the desire to contribute to society has a desire to devote not only to oneself but also to others by obtaining information through education and receiving necessary functional training for social service activities. Fifth, the desire to influence is to provide the community with an assessment of its activities. Sixth, transcendental desire is the desire to find the essential meaning of life that is more important than physical youth while experiencing a physical decline that is marked in old age[38].

In relation to these needs, preparatory education for retirement generations should cover 10 areas, including understanding the elderly, economic preparation, occupation, health promotion, death preparation, psychological stability, social activities, lifelong education, family relationships, and elderly housing. Thus, the National Occupational Competency Standards (NCS) provides examples of retirement support services by retirement type and the resulting programs[39].

Retirement support services by type are shown in [Table 1] below.

[Table 1] Retirement Support Services by Types

\begin{tabular}{|c|c|c|}
\hline Sortation & Retirement Support Services & Detailed Program Example \\
\hline $\begin{array}{l}\text { Retirement } \\
\text { preparation } \\
\text { Beginning type }\end{array}$ & $\begin{array}{l}\text { - Provide retirement support system information } \\
\text { - Lifetime design program } \\
\text { - Self-efficacy program } \\
\text { - Unreasonable belief breaking program } \\
\text { - Providing decision-making programs } \\
\text { - Provide job information } \\
\text { - Training consultation }\end{array}$ & $\begin{array}{l}\text { - Overall understanding of life stages and senior } \\
\text { citizens } \\
\text { - Economic preparation } \\
\text { - Occupation } \\
\text { - Improving and maintaining health } \\
\text { - Prepare for death and bereavement } \\
\text { - Psychological management } \\
\text { - Pursuit of self-completion } \\
\text { - Social participation in old age } \\
\text { - Smooth family relationships } \\
\text { - Housing for the elderly }\end{array}$ \\
\hline $\begin{array}{l}\text { tirement } \\
\text { preparation } \\
\text { Better type }\end{array}$ & $\begin{array}{l}\text { - Provide retirement support system information } \\
\text { - Lifetime design program } \\
\text { - Provide financial management information } \\
\text { - Working-mode programs in management mode } \\
\text { - Training consultation }\end{array}$ & $\begin{array}{l}\text { - Old age and health } \\
\text { - marital relationships, child relationships } \\
\text { - Economic preparation in old age } \\
\text { - Leisure, volunteering } \\
\text { - Testament, property inheritance }\end{array}$ \\
\hline
\end{tabular}




\begin{tabular}{|c|c|c|}
\hline $\begin{array}{l}\text { Retirement } \\
\text { preparation } \\
\text { Complete type }\end{array}$ & $\begin{array}{l}\text { - Lifetime design program } \\
\text { - Volunteer programs } \\
\text { - Investment and financial management } \\
\text { - Support for education and club activities }\end{array}$ & $\begin{array}{l}\text { - Pursuit of self-completion } \\
\text { - Improving and maintaining health } \\
\text { - Testament, property inheritance } \\
\text { - Retrospective of life } \\
\text { - volunteering }\end{array}$ \\
\hline
\end{tabular}

\subsection{NCS Career Education Development and Lifelong Education}

The characteristics of the NCS presented to the Korea Occupational Workforce are defined as follows[40]. First, the concept of competence focuses on performance-based work rather than the process of work in the industrial field. In other words, competence is concerned with what tasks workers should perform to achieve superior performance in their work rather than how they performed their work. Second, NCS focuses on activity-based behavior. In other words, knowing simple knowledge, technology, is not the key, but should be expressed in observable and assessable behavior whether knowledge, technology, etc. can produce good performance in the industrial field. Third, NCS is qualitybased; rather than simply assessing how many kinds of capabilities an individual has, it focuses on whether or not that quality of capability has reached a certain level. Fourth, NCS consists of modules. That is, NCS consists of multiple sets of capability units, which are developed by unitizing the job competence, the role that workers play within a particular occupation. Fifth, NCS is developed with industry-led participation. In other words, knowing simple knowledge, technology, is not the key, but should be expressed in observable and assessable behavior whether knowledge, technology, etc. can produce a good performance in the industrial field.

Currently, Korea is actively promoting the development and operation of an NCS-based curriculum to improve the communication and field between education and qualification systems and the quality of higher education institutions based on NCS vocational basic skills[41]. Furthermore, due to the NCSbased education policy operation and changes in the university evaluation system, Korean universities are implementing NCS curriculum reorganization, which is an essential element of all universities[41] Higher education institutions mainly aimed at vocational education such as vocational colleges and polytechnic universities are actively developing and operating curriculum-applying the National Occupational Skills Standards (NCS), and various related studies are being conducted[42].

When describing the National Occupational Competency Standards (NCS) as aspects of lifelong education[43] In a broad sense, it is a concept that covers school education and non-school education, and in consultation, it is divided into non-school education that is prepared for regular school education. According to Article 1 and Article 2 of the Lifetime Education Act, lifelong education was defined as "Lifetime education is an organized educational activity in all forms, including complimentary education, adult literacy education, vocational skills education, humanities education, culture, and arts education, and civic participation education, excluding regular curriculum in schools. In other words, lifelong education is subject to all forms of organizational, intentional and systematic educational activities other than regular curriculum. Lifetime education is the activity of maintaining the comprehensive environment associated with learning to enhance learners' willingness and ability to learn, and of maintaining and providing the necessary systems, organizations, and facilities for learning activities[44]. Lifetime learning was also defined as "organizational principles on practices and systems that satisfy the conditions of education among deliberate and systematic activities that promote learning that drives continuous and self-directed growth of experience[45]."

In the other words, the core of lifelong education is the curriculum, methods, institutions, and networks that help learners constantly reconstruct and develop their experiences through self-directed lifelong learning. On the other hand, the Korean UNESCO Committee saw in its 1973 seminar that "lifetime education is a limited period of education for people of a certain age group, which aims to maximize educational capabilities by reorganizing and strengthening the functions of social education." 
Meanwhile, a seminar by Korean UNESCO Committee (2020) described lifelong education as "a curriculum that can learn from birth to death under the basic idea of maximizing individual's potential, providing education opportunities to meet individual's needs vertically and horizontally."

\subsection{Development of NCS-based Career Education for Retired Generations}

Before preparing for the development of career education for retirement generations, various educational sites, equipment, and education manuals may be prepared depending on the type of education. In addition, it is important to arrange professional instructors that fit the type. Career development education is divided into career interactive education and career experience education, and detailed forms are described based on the following standards. The types of career education development are shown in [Table 2] below.

[Table 2] Career Education Development Form

\begin{tabular}{l|l|l}
\hline \multicolumn{1}{c|}{ Classification } & \multicolumn{1}{c|}{ Activity Contents } & \multicolumn{1}{c}{ Map Form Classification } \\
\hline Video Media & $\begin{array}{l}\text { Audiovisual data utilization time allows you to have an opportunity to } \\
\text { learn about different occupations }\end{array}$ & $\begin{array}{l}\text { Discussion type } \\
\text { (career interactive) }\end{array}$ \\
\hline $\begin{array}{l}\text { a } \\
\text { professional } \\
\text { worker }\end{array}$ & $\begin{array}{l}\text { You will listen to lectures from professionals in various fields, such as } \\
\text { corporate CEOs, incumbent people, and experts, to promote a deep } \\
\text { understanding of jobs and lives through this. }\end{array}$ & $\begin{array}{l}\text { Lecture type } \\
\text { (career interactive) }\end{array}$ \\
\hline Field trip type & $\begin{array}{l}\text { Learning activities in which students visit companies, museums, public } \\
\text { institutions, etc. for career education to collect information, find out } \\
\text { how they are related to their jobs or careers, and write reports. }\end{array}$ & $\begin{array}{l}\text { Field trip type } \\
\text { (Career experience type) }\end{array}$ \\
\hline $\begin{array}{l}\text { Department } \\
\text { experience type }\end{array}$ & $\begin{array}{l}\text { Faculty experience provides a wide range of job search opportunities } \\
\text { and basic knowledge or skills learning opportunities required by the } \\
\text { professional world }\end{array}$ & $\begin{array}{l}\text { Department experience type } \\
\text { (Career experience type) }\end{array}$ \\
\hline $\begin{array}{l}\text { Field job } \\
\text { Experience type }\end{array}$ & $\begin{array}{l}\text { Two to five students will experience simple tasks through meetings with } \\
\text { mentors from various occupational groups, explore the job world, and } \\
\text { learn how to work. }\end{array}$ & $\begin{array}{l}\text { Field job } \\
\text { Experience type } \\
\text { (Career experience type) }\end{array}$ \\
\hline Camp type & $\begin{array}{l}\text { To intensively operate programs for career education in a specific place } \\
\text { in a short period of time (operating for at least six hours a day). }\end{array}$ & $\begin{array}{l}\text { Camp type } \\
\text { (Career experience type) }\end{array}$ \\
\hline Consignment type & $\begin{array}{l}\text { To entrust students' career experience through contracts with agencies } \\
\text { and select and implement career experience methods and institutions } \\
\text { through consultation with entrusted agencies and schools. }\end{array}$ & $\begin{array}{l}\text { Institutions inner } \\
\text { operation }\end{array}$ \\
\hline
\end{tabular}

The form of career education development may be used by mixing indirect experience type, field trip type, field job experience type, and camp type. In addition, prior preparation was conducted for each type of education, and it can be conducted through discussion-type classes or lecture-type classes by inviting experts from each job group. Depending on the characteristics of retirement generations, it will also be possible to plan customized curriculum for small groups depending on their age group.

\subsection{Career Education Development Manual}

To prepare for the development of career education based on NCS for retirement generations, a manual for career education development must be preceded first. The career education development manual can be divided into stages of self-awareness, exploration, preparation for a career path, and 
improvement of career path by career step. In addition, the career education development manual can be used by consulting with professors, modifying and supplementing the contents by referring to the standardized education manual by following per under various types of career education.

The career education development manual is as shown in [Table 3].

[Table 3] Career Education Development Manual

\begin{tabular}{|c|c|c|c|c|c|}
\hline & & \multirow[t]{2}{*}{ Detailed Topic } & \multirow[t]{2}{*}{ Question } & \multicolumn{2}{|c|}{ Application } \\
\hline & & & & $\mathrm{Y}$ & $\mathrm{N}$ \\
\hline \multirow{4}{*}{\multicolumn{2}{|c|}{$\begin{array}{l}\text { 1. Career path } \\
\text { Stage }\end{array}$}} & Career recognition & Start worrying about your career, reflect on yourself. & $\sqrt{ }$ & \\
\hline & & Career exploration & $\begin{array}{l}\text { Explore and choose the right career path, and experience a } \\
\text { variety of things. }\end{array}$ & $\sqrt{ }$ & \\
\hline & & Career preparation & $\begin{array}{l}\text { Systematic preparation for selected career path practical } \\
\text { activity experience }\end{array}$ & $\sqrt{ }$ & \\
\hline & & $\begin{array}{l}\text { Career maintenance \& } \\
\text { improvement }\end{array}$ & Connecting jobs with confidence in one's career path & $\sqrt{ }$ & \\
\hline \multirow{6}{*}{\multicolumn{2}{|c|}{$\begin{array}{l}\text { 2. Career path } \\
\text { Core Capabilities }\end{array}$}} & Self-understanding & Increase your understanding of yourself & $\sqrt{ }$ & \\
\hline & & Select a goal & $\begin{array}{l}\text { Planning and implementing clear goals regarding career } \\
\text { path }\end{array}$ & $\sqrt{ }$ & \\
\hline & & Self-directed & $\begin{array}{l}\text { Be confident of your career path and engage yourself in } \\
\text { career activities. } \\
\text { Troubleshooting }\end{array}$ & $\sqrt{ }$ & \\
\hline & & Solving the problem & Solving Career Problems & $\sqrt{ }$ & \\
\hline & & Information collection & Collecting job information and meet people involved & $\sqrt{ }$ & \\
\hline & & Future plan & Establish and implement specific future plans & $\sqrt{ }$ & \\
\hline \multirow{5}{*}{\multicolumn{2}{|c|}{$\begin{array}{l}\text { 3. Activity } \\
\text { Form }\end{array}$}} & Field trip type & Experience in the form of a field of interest & $\sqrt{ }$ & \\
\hline & & Career experience type & $\begin{array}{l}\text { Specific experience of career path (japworld, experience } \\
\text { booth, etc.) }\end{array}$ & $\sqrt{ }$ & \\
\hline & & Lecture type & Training on career path through lecture type & $\sqrt{ }$ & \\
\hline & & Career camp & Intensive career education $\&$ activities through camp & & $\sqrt{ }$ \\
\hline & & $\begin{array}{l}\text { Occupational experience } \\
\text { type }\end{array}$ & Direct job experience on the job site & $\sqrt{ }$ & \\
\hline 4. $\mathrm{P}$ & \multirow{4}{*}{ Target } & Elementary school student & elementary school student program & & $\sqrt{ }$ \\
\hline o & & Middle school student & Middle school student program & & $\sqrt{ }$ \\
\hline $\begin{array}{l}\mathrm{g} \\
\mathrm{r}\end{array}$ & & A high school student & Professional high schools, programs for alternative schools & & $\sqrt{ }$ \\
\hline $\mathrm{C}$ & & Mixed type & Operate without special restrictions & $\sqrt{ }$ & \\
\hline $\mathrm{n}$ & \multirow{3}{*}{ PerIod } & Even type & One or two programs in the form of events & $\sqrt{ }$ & \\
\hline $\begin{array}{l}\mathrm{f} \\
\mathrm{I}\end{array}$ & & Regular type & $\begin{array}{l}\text { Program of sustainable form at least three times in the } \\
\text { same group }\end{array}$ & $\sqrt{ }$ & \\
\hline $\mathrm{u}$ & & In a year & Continuous programs for a year & $\sqrt{ }$ & \\
\hline $\mathrm{a}$ & \multirow{3}{*}{$\begin{array}{l}\text { Activities } \\
\text { method }\end{array}$} & Career diagnosis & Diagnostics to analyze career path & $\sqrt{ }$ & \\
\hline I & & Cooperative activities & Proceed with the program through cooperative activities & $\sqrt{ }$ & \\
\hline $\mathrm{n}$ & & Project & Proceed with a team or individual project & $\sqrt{ }$ & \\
\hline
\end{tabular}




\begin{tabular}{|c|c|c|c|c|}
\hline & Game & Apply game elements & $\sqrt{ }$ & \\
\hline & Lecture & $\begin{array}{l}\text { Communicate large amounts of information through } \\
\text { lecture techniques }\end{array}$ & $\sqrt{ }$ & \\
\hline & Consulting & A group of experts conducts consulting on career paths. & $\sqrt{ }$ & \\
\hline & Mentoring & Mentoring through career mentors & $\sqrt{ }$ & \\
\hline \multirow{4}{*}{$\begin{array}{c}\text { Human } \\
\text { Composition }\end{array}$} & Internal leader & Directly operated by internal leaders & & $\sqrt{ }$ \\
\hline & Professional instructor & Proceed with the use of external career progress. & $\sqrt{ }$ & \\
\hline & volunteer work & Proceed using volunteer work & & $\sqrt{ }$ \\
\hline & the person in question & Directing career activities by the employee concerned & & $\sqrt{ }$ \\
\hline
\end{tabular}

The most important thing in the Career Education Development Manual is to apply the appropriate types of activities for the development of necessary core competencies at each stage based on the level of career activities as shown in [Table 3]. This study aims to enhance the effectiveness of the program by combining various activities to reflect the retirement generation's various career needs.

\section{Conclusion}

\subsection{Conclusion}

NCS is a system that reorganizes vocational education, training, and qualification systems to meet the requirements of the industrial site based on the national job competency standards and encourages companies to hire and manage human resources. The goal is to improve worker satisfaction and reduce turnover through human resources management as a system that can utilize overall human resources management such as promotion, placement, and wages when education development by NCS-based level is utilized. According to the purpose of this study, a curriculum approach suitable for the retirement generation indicates that career needs and job needs should be reflected by selecting talent by creating job details and job evaluation standards.

The NCS's classification system identifies what information is provided for each job, identifies the stepwise composition of the national job competency standards centered on the type of job, and presents an overall roadmap for the development of the national job competency standards[1]. The standardization process of job competence is carried out systematically and step-by-step with the Korean Employment Classification of Occupations (KECO), referring to the Korean Standard Occupation Classification, and Korean Standard Industry Classification. Tasks are organized in the order of large categories (division, groupings, and classifications), and can be summarized in detail through a systematic diagram explaining how the NCS is structured.

Career development education for retired generations is as follows. First, it is about helping the retirement generation understand their tendencies, such as aptitude and ability. Second, the purpose is to broaden understanding of various jobs and develop the necessary knowledge, skills, and attitudes of these jobs. Third, it is to carefully select and explore the information and experience needed to prepare for areas where one can develop one's aptitude and abilities in various occupations.

In addition, career development education has the following educational characteristics: First, career development education requires a process of broadening and understanding various job sites, so the development of attitudes toward jobs through field-oriented experience education should also be important. Second, the educator should prioritize motivational education on the learner's career path, so that the curriculum should be designed based on the required analysis of the learner's development 
stages, characteristics, and various interests, and an open curriculum should be modified with continuous feedback. Third, the method of career development education can be constructed based on autonomous participation principles that learners can directly participate in and through self-directed learning.

\subsection{Suggestion}

Middle-aged and old men are looking for a variety of education and information after retirement with numerous concerns and efforts about the quality of life. Recently, the retirement generation needs to develop various career education as their educational background is higher than the past generation and more professional retirees are increasing. The study can plan a curriculum that includes 10 areas of understanding of old age, economic preparation, occupation, health promotion, death preparedness, psychological stability, social activities, lifelong education, family relationships, and elderly housing. The curriculum for large and small groups is also available depending on the individual circumstances and needs of participants. Modern society is changing rapidly and needs to be flexible in dealing with anxiety and social stress about the future. In particular, they experience the burden of their age and family. Retired generations are concerned about their health due to their physical strength and complications as they enter old age, and they hope to remain a father who can remember their relationship with his wife and children, unlike in the past when they lived like workaholics. However, if retirement preparation is considered specifically based on self-understanding for a successful retirement, life after retirement will act as a more hopeful factor to find oneself and restore their selfesteem. In other words, men will need to explore new careers at any point in their lives and develop career education and vocational education to actively seek careers. Therefore, it is necessary to continuously intervene in career education for retirement generations in terms of lifelong education. Based on this, the career education process should also be considered as regional characteristics and environments are different from the environment and conditions of lifelong education by individual needs and region. Rather than forcing generalization, it is effective to use tools that can be customized based on career curriculum and manual.

Thus, to fully embrace career education development and lifelong learning, society must rethink that learning and education take place 'life-long' and 'life-wide'. Lifetime learning has a wide range of learning paths, spaces, and forms, allowing everyone, from children to middle-aged retirement generations, to enjoy the benefits of a learning experience anytime, anywhere.

This study seeks to help the middle-aged and senior citizens with educational background, knowledge, and professional social experience to have the opportunity to design successful retirement in pursuit of positive meaning of life for retirement generations. This study seeks to help middle-aged and senior citizens with educational background, knowledge, and professional social experience to have the opportunity to design successful retirement in pursuit of the positive meaning of life for retirement generations.

\section{Reference}

[1] K. S. Park, Exploring the effectiveness of vocational competency improvement education and psychological changes after re-employment among women with career interruptions, Gwangju University, Doctoral Dissertation, (2021)

[2] D. I. Kim, G. S. Park, M. N. Lee, B. N. Kim, Lifelong Education Theory, History of Education and Science, (2021)

[3] E. Bonsang, S. Adam, S. Perelman, Does retirement affect cognitive functioning?, Journal of Health Economics, (2012), Vol.31, No.3, pp.490-501, DOI: https://doi.org/10.1016/j.jhealeco.2012.03.005

[4] H. R. Kim, A phenomenological study of life experiences after retirement of middle school male teachers, Hansei 
University graduate school, Doctoral Dissertation, (2021)

[5] J. E. Son, Life Satisfaction Study of Middle and Older Retirees: Using the 2nd (2008)-7th (2018) Aging Research Panel Survey, Yonsei University, Master Thesis, (2021)

[6] H. B. Oh, The effect of subjective perception of socioeconomic status on quality of life: Focusing on overall quality of life satisfaction and health satisfaction, Seoul National University, Master Thesis, (2010)

[7] T. M. Skovhlt, Career themes in counseling and psychotherapy with Men, American Association for counseling and Development Press, (1989)

[8] B. L. Neugarten, R. J. Havinghurst, S. S. Tobin, The Measurement of Life Satisfaction, Journal of Gerontology, (1961), Vol.16, No.2, pp.134-143, DOI: https://doi.org/10.1093/geronj/16.2.134

[9] B. R. Lee, J. G. Lee, Comparison of the effects of economic and social participations on the life satisfaction of old adults, Korean Journal of Gerontological Social Welfare, (2016), Vol.71, No.2, pp.351-377.

[10] M. H. Yang, Influencing factors on psychological well-being of male retirees, Seoul Christian University graduate school, Doctoral Dissertation, (2012)

[11] H. Y. Shin, An exploratory study of husbands retirement and changes in marital relationships: A comparison of perceptions between wives and husbands, Duksung Journal of Social Sciences, (1996), Vol.4, pp.117-131.

[12] G. Y. Choi, I. H. Cho, E. H. Lee, A qualitative study on retirement of Korean older workers, Journal of the Korea Gerontological Society, (2001), Vol.21, No.1, pp.73-92, URI: http://hdl.handle.net/10203/80496

[13] S. B. Park, Analysis of the needs for successful aging of professional retirees: focusing on competency, learning and social activity, Kyungsung University graduate school, Doctoral Dissertation, (2010)

[14] M. S. Park, A study on good use of leisure among the retired elderly in Korea, Family and Environment Research, (2004), Vol.42, No.12, pp.107-122, UCI: G704-000012.2004.42.12.013

[15] I. A. Connidis, Siblings as friends in later life, American Behavioral Scientist, (1989), Vol.33, No.1, pp.81-93, DOI: http://dx.doi.org/10.1177/0002764289033001008

[16] J. E. Mutchler, J. A. Burr, A. M. Pienta, M. P. Massagli, Pathways to labor force exit: Work transitions and work instability, Journal of Gerontology, (1997), Vol.52, No.1, pp.4-12, DOI: https://doi.org/10.1093/geronb/52B.1.S4

[17] E. P. Lazear, Chapter 5 Retirement from the labor force, Handbook of labor economics, (1986), Vol.1, pp.305-355, DOI: https://doi.org/10.1016/S1573-4463(86)01008-8

[18] J. W. Rowe, R. L. Kahn, Successful Aging, Gerontologist, (1997), Vol.37, No.4, pp.433-440, DOI: https://doi.org/10.1093/geront/37.4.433

[19] C. Hertzog, A. F. Kramer, R. S. Wilson, U. Lindenberger, Enrichment effects on adult cognitive developments: Can the functional capacity of older adults be preserved and enhanced?, Psychological Science in the Public Interest, (2008), Vol.9, No.1, pp.1-65, DOI: 10.1111/j.1539-6053.2009.01034.x

[20] J. H. Bae, A Study on the Effects of Retirement in the Elderly on Cognitive Function: Focusing on the Korean Aging Panel Data (KLoSA), Korea University graduate school, Master Thesis, (2021)

[21] R. A. Ward, Marital happiness and household equity in later life, Journal of Marriage and Family, (1993), Vol.55, No.2, pp.427-438, DOI: https://doi.org/10.2307/352813

[23] S. M. Kim, S. Y. Kim, A study on aging anxiety and self efficacy of middle aged adults, Journal of Korean Academy Psychiatric and Mental Health Nursing, (2008), Vol.17, No.3, pp.281-291, UCI: G704-001695.2008.17.3.008

[24] E. H. Erikson, Identity: youth and crisis, W. W. Norton Company, (1968)

[25] H. S. Yoon, M. J. Lee, The impact of retirement on psychological well-being of the elderly, Journal of the Korea Gerontological Society, (2007), Vol.27, No.2, pp.393-408, UCI: G704-000573.2007.27.2.003

[26] S. Coopersmith, The antecedents of self-esteem, W. H. Freeman, (1967)

[27] S. M. Lim, The effects on life satisfaction in retirement preparation and residential environment of the middle-aged : 
focused on the moderating effects of social capital, Hoseo University, Doctoral Dissertation, (2016)

[28] H. O. Jeon, Grounded theory approach on the women's adaptation experience with their retired husbands, Journal of Qualitative Research, (2008), Vol.9, No.2, pp.120-128.

[29] Rosenberg Morris, Conceiving the self, New York: Basic Books, (1979)

[30] William Howard Fitts, W. L. Warren, Western Psychological Services, Tennessee self-concept scale: TSCS-2 manual, Western Psychological Services, (1996)

[31] B. W. Lee, The effect of attachment factors and self-esteem in adolescents on career maturity, Sookmyung Women's University graduate school, Master Thesis, (2008)

[32] J. W. Rowe, R. L. Kahn, Successful aging, Dell, (1999)

[33] E. L. Deci, R. M. Ryan, Intrinsic motivation and self-determination in human behavior, Plenum Press, (1985)

[34] M. H. Lee, A study on the development and validation of basic psychological needs scales based on the theory of selforganization, Ewha Womans University, Master Thesis, (2007)

[35] J. H. Lim, J. H. Rye, The impact of self-determination on academic achievement of elementary students, The Korean Journal of Educational Methodology Studies, (2007), Vol.19, No.2, pp.163-181, DOI : 10.17927/tkjems.2007.19.2.163

[36] A. Y. Kim, S. N. Oh, Classification of Motivation on the Continuum of Self-Determination, Korean Journal of Educational Psychology, (2001), Vol.15, No.4, pp.97-119.

[37] 2011.2012 Lifelong Education White Paper, Ministry of Education, National Institute for Lifelong Education, pp.6-9, (2013)

[38] J. S. Kwen, A narrative exploration of the change in life goals of retired men who face successful old age, Hansei University graduate school, Doctoral Dissertation, (2021)

[39] Ministry of Education, Retirement counseling, Korea Vocational Competency Development Institute, (2020)

[40] Y. R. Kim, S. C. Choi, T. J. Lee, W. Y. Yun, A Research on Continuous Quality Improvement of NCS - Based Curriculum -In the Case of Department of Tax Accounting \& Information in K College University-, Tax Accounting Research, (2015), No.46, pp.107-131, DOI : 10.35349/tar.2015..46.006

[41] D. Y. Kim, J. S. Kim, A study on the validity of the NCS-based vocational curriculum development procedure model recognized by experts in developing national competency standards, Journal of Korean Institute of Industrial Educators, (2015), Vol.40, No.1, pp.64-86.

[42] E. H. Lee, A comparative study on the organization of general curriculum for key competencies, Asian Journal of Education, (2006), Vol.7, No.1, pp.83-110, UCI: G704-000733.2006.7.1.006

[43] Y. M. Nam, I. R. Kim, Current status and tasks of lifelong education in Chungbuk, Chungbuk Research Institute, (2017), Vol.143, pp.1-16.

[44] Ki Hwan Li, A Study on Learner's Motive of Participation and Satisfying Degree in The Program for Lifeling Education: With lifelong education by government and public offices in the center, Department of Community Development Graduate School of Daegu University, p.1, (2003)

[45] S. H. Han, Lifelong Education Theory: Pedagogy in a Lifelong Learning Society, Hakjisa, (2004) 